John Carroll University

Carroll Collected

2019

\title{
College Students' Views on Drug Policy in the United States: The Impact of Reading Michelle Alexander's The New Jim Crow
}

Richard D. Clark

John Carroll University, rclark@jcu.edu

Gloria S. Vaquera

John Carroll University, gvaquera@jcu.edu

Kenneth S. Chaplin

John Carroll University, kchaplin@jcu.edu

Follow this and additional works at: https://collected.jcu.edu/fac_bib_2019

Part of the Criminology Commons

\section{Recommended Citation}

Clark, Richard D.; Vaquera, Gloria S.; and Chaplin, Kenneth S., "College Students' Views on Drug Policy in the United States: The Impact of Reading Michelle Alexander's The New Jim Crow" (2019). 2019 Faculty Bibliography. 36.

https://collected.jcu.edu/fac_bib_2019/36 


\title{
College Students' Views on Drug Policy in the United States: The Impact of Reading Michelle Alexander's The New Jim Crow
}

\author{
Richard D. Clark, Gloria S. Vaquera and Kenneth S. Chaplin
}

\begin{abstract}
Using a quasi-experimental research design to test the "Marshall Hypothesis," we investigated the effects of reading Michelle Alexander's The New Jim Crow: Mass Incarceration and the Age of Colorblindness on college students' views of drug policy in the United States. One hundred and twenty-eight undergraduate students at a predominantly white Midwest university took part in this study. Test subjects read the text and took both a pre- and posttest questionnaire, while a control group of students, who did not read the book, was also surveyed concerning their views on drug policies. Additionally, reflective essays written by the test population were also analyzed. Findings offer limited support for the Marshall Hypothesis, which asserts that a properly informed constituency would conclude that certain policies in the U.S. are unjust. Students, in general, showed significant changes in their perceptions of drug policies after reading the text. However, disaggregating students by gender showed that female students, more than male students, are more convinced by Alexander's arguments that current drug policy unfairly target communities of color.
\end{abstract}

\section{Introduction}

Nationwide, we have seen a sudden change in attitudes toward American drug policy. More and more, we witness public officials and law enforcement openly questioning the benefits of the "War on Drugs" (Abramsky, 2009; Resnick, 2015; Zedillo \& Wheeler, 2012). Public officials who previously called for stiff jail penalties for drug offenses are now supportive of treatment and de-incarceration as an alternative. In this changing landscape, legal scholar, Michelle Alexander's (2010) The New Jim Crow: Mass Incarceration and the Age of Colorblindness was released and spent six weeks on the New York Times best seller list. Touted as "invaluable" and "a stunning piece of scholarship" by reviewers, her book challenges America's "War on Drugs" and calls attention to the devastating impact this policy has had on African-Americans. Through factladen prose, Alexander argues that our drug policies have created a racial system of 
control that compares to Jim Crow segregation by producing a second-class citizenry that is denied full rights. This convincing book has been read by hundreds of thousands of people and has even made Facebook creator Mark Zuckerberg's, "Year of Books" list as a must read (Feloni, 2015).

Such an influential book perhaps does influence public opinion and relates to the Marshall Hypothesis. Thurgood Marshall, member of the United States Supreme Court from 1967 to 1991, created the Marshall Hypothesis in a consenting opinion in the 1972 Furman v. Georgia case. Marshall believed that people supported the death penalty because they were not informed of the realities of it. He hypothesized that informed citizens would believe that the death penalty was indeed "shocking, unjust and unacceptable." Thus, exposure to information should change the average citizen's opinion on this topic. Paralleling Marshall's hypothesis on the death penalty, we attempted to test whether additional information on mass incarceration would change students' opinions regarding the efficacy of large-scale imprisonment. Using Professor Alexander's book The New Jim Crow as the vehicle, we assessed whether increased information on mass incarceration, as a result of racial bias, would change students opinions regarding its morality.

\section{Marshall hypothesis}

In examining attitudes toward the death penalty, various researchers have used college student populations to test the Marshall Hypothesis. Generally using a pretest and posttest model, researchers have exposed students to readings and information on the death penalty to assess if such exposure resulted in changed attitudes regarding the death penalty. Overall, researchers have found general support for the Marshall Hypothesis; that is, additional information on the death penalty has shifted student positions from support to nonsupport. Such findings were originally noted by Sarat and Vidmar (1976) in a community based survey. Using a pretest and posttest design with two 1,500 word essays on the death penalty as the "intervention," Sarat and Vidmar found that those with little knowledge regarding the death penalty exhibited the largest swing toward favoring abolition. Respondents who were originally more knowledgeable on the subject showed no significant change in attitude in the posttest data. Using various samples of undergraduate students taken from both criminology and general studies courses, similar findings on the efficacy of knowledge and attitudes toward the death penalty were noted by Bohm, Clark and Aveni (1991); Cochran and Chamlin (2005); LaChappelle (2012); Lambert, Camp, Clarke and Jiang (2011); Lambert and Clarke (2001); Mallicoat and Brown (2008); Michel and Cochran (2011); and Mitchell (2006).

Within studies that examine the Marshall hypothesis, the influence of a person's gender has also been considered. Focusing on women, the data suggests that historically women have been less likely to support the death penalty (Cochran \& Sanders, 2009; Gallup, 2013; Pew Research Center, 2015). Attempts have been made to explain the gender differences in death penalty support. In an analysis of the 1990 General Social Survey data, Stack (2000), for example, found little difference between factors that drove death penalty support for men and women, with the exception of the level of authoritarianism which was more influential for women. Stack concluded that there 
was no need for a gendered theory to examine death penalty support because traditional models worked well for both men and women. This conclusion was supported by Lambert, Clarke, and Lambert (2004), who explored death penalty attitudes by gender among college students at a public four-year university in Michigan. While they noted a statistically significant gender influence, they also found that the contribution of gender in the OLS regression model was rather small. Thus, they concluded that the variable measuring gender (male vs. female) was most likely a proxy variable for other underlying attitudinal determinates.

Other studies have found more definitive support for a gender-based explanation to examine differences in death penalty support. Utilizing survey data from the National Opinion Research Center, Cochran and Sanders (2009) attempted to explain the gender difference in death penalty support. Their analysis found little explanatory support for the difference, although they did conclude that perhaps increased feelings of empathy among women may account for some of the difference. Additional research has suggested other variables that may influence gender differences. In a follow-up to an earlier research effort utilizing college students from the United States and India, Lambert et al. (2016), noted that men were driven more by attitudes of deterrence and retribution, whereas women were more influenced by concerns over rehabilitation, innocence, and morality. Michel and Cochran's (2011) study of 365 upper-level undergraduate criminology majors and minors concluded that while the results were mixed, knowledge of the death penalty was related to decreased support among whites and males. These researchers theorized that support for the death penalty dropped more significantly for whites and males due to their originally stronger support for the death penalty. In an attempt to explain gender differences, Michel and Cochran speculated that women's role in care-giving as well their status as a "minority" with diminished societal power may influence their opposition to the death penalty. Women, therefore, may be more empathetic to other marginalized populations.

\section{Acceptance of racial bias in policing}

The previous literature has focused on research that attempts to test the Marshall Hypothesis in regards to attitudes about the death penalty with the premise being that more knowledge on the topic will result in less support for this policy. Alexander's The New Jim Crow presents convincing information about the racial implications of our drug policy; however, unlike the death penalty, Alexander's position requires the reader to accept that racism exists and that the policies, as they have been enforced, detrimentally impact minorities more than whites. As such, this text is a critique of the policy and also the structural racism that exists today in the United States.

For decades, researchers have found that a citizens' attitude toward the police and the courts are impacted by the race of the individual. Studies have found that communities of color have a more negative view of the police and courts than do nonminority subjects (Lee \& Gibbs, 2015; Lewis, Wilks, Geiger, Barthelemy, \& Livermore, 2017; Mbuba, 2010; Oliveira \& Murphy, 2015; Weitzer, 2015; Weitzer \& Tuch, 1999). One theory that has been posited to explain racial differences in attitudes toward the police has been Blumer's (1958) group position theory. According to Blumer's theory, US race 
relations are mediated by a desire for the dominant group to maintain its position and for the subordinate group to resist. In this conflict perspective, the criminal justice system is viewed as a potential tool for white citizens to maintain group position. A recent national survey of 4,538 US adults on views of the police indicate that black respondents are half as likely as whites to have a positive view of the job that their local police are doing (Morin \& Stepler, 2016). This same survey also found that only $33 \%$ of African Americans, as compared to $75 \%$ of white Americans, say that the police are doing an "excellent" or "good" job in their communities. Furthermore, only $14 \%$ of black respondents say that they have a lot of confidence in their local police as compared to $42 \%$ of whites.

Similarly, studies on college student attitudes toward police have also revealed this racial divide. In a study of college students in the Baton Rouge metropolitan area, Lewis et al. (2017) examine attitudes toward the police in an area of recent high profile police shootings. Their study found significant racial differences with black students reporting stronger agreement with the statement that minorities are more likely to become victims of police brutality than white citizens. Black students also had higher levels of affirmation with statements about the need for police to have more training to de-escalate situations and be more culturally competent. In another part of the U.S., Mbuba's (2010) study at a large Midwestern university found that students of color were more affirming with the statement "police unfairly target racial minorities." Furthermore, minority students showed less support for the idea that "police provide an important service in the community." In addition to considering issues of race, this study examined gender differences and found that male students were less positive toward the police than female students. While both males and females disagreed that police were corrupt, females showed higher levels of disagreement. Males also responded more positively to the statement that reporting crime to the police could "result in the police turning on them." Thus, males more than females were more suspicious of the police.

In considering the impact of gender on attitudes toward police, Mbuba's (2010) study did not find differences between males and females regarding beliefs about racial biases in policing. Studies on racial prejudice, however, have found that women tend to have less prejudicial attitudes than men (Carter, 1990; Qualls, Cox, \& Schehr, 1992; Terenzini, Pascarella, Springer, Nora, \& Palmer, 1996). Qualls et al.'s (1992) study of undergraduates found that white female students were more accepting of racial minorities and reportedly engaged in less discriminatory behavior. Similarly, in their three-year study of 1,061 white undergraduates at 17 colleges and universities, Terenzini et al. (1996) found that women had more favorable attitudes toward diversity, even after controlling for the "liberalness" of their selected majors.

Given past research, this study seeks to investigate the Marshall Hypothesis for its impact on students' perceptions that drug policies are racially unjust. In addition, gender differences in perceptions are explored in this sample of predominantly white students. The following hypotheses are tested:

H1: Reading The New Jim Crow raises awareness on the realities of the War on Drugs and incarceration and will make students less likely to believe that the police and courts treat people of all races equally. 
H2: Male subjects, in comparison to female subjects, reading The New Jim Crow, will show less change in perceptions that the police and the courts treat communities of color unfairly.

\section{Methods}

During the first few weeks of the semester, students in selected Criminology courses were administered a survey. Data was collected over two semesters in the 2015-2016 academic year. These subjects, the test population, were then required to read Alexander's The New Jim Crow. During the same period of time, two sections of an Introduction to Sociology course were also surveyed and were identified as the control group. The populations of the test group and the control group were similar in gender and racial representation. Several weeks into the semester, the Criminology students read The New Jim Crow. After reading the text and participating in class discussions about its contents, each student wrote a response paper. The pretest was administered early within the second week of the semester. The "critical book review" of The New Jim Crow was due at the end of week five, and the posttest was administered early in week six of the semester. Prior to the posttest, the War on Drugs was not discussed in the course. The instructions for the response paper asked students to "include in your review a description of what the author said and your reaction to it. What is your impression of her message? Do you agree or disagree? Why? This review will be graded on a 0 to 100 scale." The verbal prompt that accompanied the assignment was to: "Show me through your writing that you read the book and understood her message. Articulate her overall message, and your reaction to that overall message. Do you agree or disagree with her assessment regarding Mass Incarceration and the War on Drugs? Explain and defend your answer."

After omitting incomplete surveys, our sample consisted of 128 students, 66 women, and 62 men who attended a predominantly white, liberal arts university. 89\% of this sample identifies as "white," with the remaining $11 \%$ identifying as "non-White" or "other." Over the course of two semesters, data was drawn from students enrolled in Criminology (test subjects, $N=63$ ) or Introduction to Sociology courses (control subjects, $N=65)$.

\section{Instruments}

To test the Marshall Hypothesis two methods are employed, one quantitative and the other qualitative. A survey instrument, comprised mostly of Likert scale items to examine subjects' knowledge and perceptions of the drug policy in the United States was created. Modifying a public opinion survey conducted by CBS News and the New York Times (1989), perceptions of drug sentencing and treatment of felons is measured, along with content-specific questions that measure a student's understanding of the main points in The New Jim Crow. Additionally, a self-reflective writing prompt was assigned to examine how reading the text had impacted the perspectives of these students on the US drug policy. 
Table 1. Descriptive statistics for the control group and test group data.

\begin{tabular}{|c|c|c|c|c|c|}
\hline Variable & $N$ & Minimum & Maximum & Mean & Std. Deviation \\
\hline \multicolumn{6}{|c|}{ NJC Knowledge } \\
\hline Control & 65 & 0 & 3 & 1.4 & 0.74 \\
\hline Pretest & 63 & 0 & 4 & 2.25 & 0.91 \\
\hline Posttest & 63 & 2 & 5 & 2.97 & 0.77 \\
\hline \multicolumn{6}{|c|}{ Police treat all racial groups equally } \\
\hline Control & 65 & 1 & 4 & 2.05 & 0.82 \\
\hline Pretest & 63 & 1 & 4 & 1.93 & 0.77 \\
\hline Posttest & 63 & 1 & 4 & 1.76 & 0.71 \\
\hline \multicolumn{6}{|c|}{ Courts treat all racial groups equally } \\
\hline Control & 65 & 1 & 4 & 2.29 & 0.76 \\
\hline Pretest & 63 & 1 & 4 & 2.04 & 0.79 \\
\hline Posttest & 63 & 1 & 4 & 1.81 & 0.69 \\
\hline \multicolumn{6}{|c|}{ The War on Drugs primarily targets people of color ${ }^{\mathrm{a}}$} \\
\hline Control & 65 & 1 & 4 & 2.44 & 0.69 \\
\hline Pretest & 63 & 1 & 4 & 2.36 & 0.87 \\
\hline Posttest & 63 & 1 & 4 & 1.86 & 0.76 \\
\hline
\end{tabular}

${ }^{\mathrm{a}}$ Item was reverse coded.

\section{Description of quantitative measures}

To examine how exposure to The New Jim Crow would raise awareness about the realities of the War on Drugs and incarceration, five content-specific questions are asked regarding drug policies that are discussed in the book: the percentage of all drug abuse arrests for marijuana in 2011; the type of person most likely to be arrested for drugs; the increase in percentage of drug arrests resulting in prison sentences since 1980; the increase since 1980 of the number of people in prison for drug offenses; and the number one offense connected to new prison admission since the 1990s. Taken together, these five items create a composite variable, NJC Knowledge.

We measure perceptions of unequal treatment for racial minorities through the use of three questions. All three are Likert scale questions where we ask the students to state their degree of agreement with two statements, one assessing if they feel that the police act fairly and the other measuring whether they feel the court system is fair toward all racial groups. Responses are scored from $4=$ strongly agree to $1=$ strongly disagree. The final question asks about their degree of agreement with this statement: The War on Drugs primarily targets people of color. To facilitate interpretation of the data, this item was reverse coded to match the direction of the previous two items. Thus, students with lower scores on these items indicate a belief in the racial bias of police, courts, and the War on Drugs.

\section{Results}

In this study, a test and a control population are examined across three Likert scale items used to measure perceptions of racial bias in the justice system. One composite measure of knowledge is used for comparison across these groups. The results of these descriptive statistics are provided in Table 1. With all four variables, the control, pretest, and posttest groups show a difference in means. The posttest score of NJC Knowledge was the highest measuring knowledge gained by reading the text. For the 
Table 2. Comparison of control groups, experimental pretest and posttest measures.

\begin{tabular}{|c|c|c|c|c|c|c|c|}
\hline \multirow[b]{3}{*}{ Variable } & \multirow{2}{*}{\multicolumn{3}{|c|}{ Mean (SD) }} & \multicolumn{4}{|c|}{ Post-hoc comparison $^{\text {b }}$} \\
\hline & & & & & \multicolumn{3}{|c|}{ Mean difference (Std. error) } \\
\hline & $\begin{array}{c}\text { Control } \\
(n=65)\end{array}$ & $\begin{array}{c}\text { Experimental } \\
\text { pretest } \\
(n=63)\end{array}$ & $\begin{array}{c}\text { Experimental } \\
\text { posttest } \\
(n=63)\end{array}$ & ANOVA $(F)^{\mathrm{a}}$ & $\begin{array}{c}\text { Control vs. } \\
\text { pretest }\end{array}$ & $\begin{array}{c}\text { Control vs. } \\
\text { posttest }\end{array}$ & $\begin{array}{c}\text { Pretest vs. } \\
\text { posttest }\end{array}$ \\
\hline NJC Knowledge & $1.4(.74)$ & $2.25(.91)$ & $2.97(.77)$ & $63.41 * * *$ & $-.894(.11)^{* * *}$ & $-1.24(.10)^{* * *}$ & $-.34(.11)^{*}$ \\
\hline $\begin{array}{l}\text { Police treating } \\
\text { all racial } \\
\text { groups equally }\end{array}$ & $2.05(.82)$ & $1.93(.77)$ & $1.76(.71)$ & 2.21 & $.120(.13)$ & $.284(.14)^{+}$ & $.163(.13)$ \\
\hline $\begin{array}{l}\text { Courts treating } \\
\text { all racial } \\
\text { groups equally }\end{array}$ & $2.29(.76)$ & $2.04(.79)$ & $1.81(.69)$ & $6.63^{* *}$ & $.248(.13)$ & $.482(.13)^{*}$ & $.235(.13)$ \\
\hline $\begin{array}{l}\text { The War on Drugs } \\
\text { primarily targets } \\
\text { people of color }\end{array}$ & $2.44(.69)$ & $2.36(.87)$ & $1.86(.76)$ & $10.66^{* * *}$ & $.088(.13)$ & $.590(.14)^{* * *}$ & $.501(.14)^{*}$ \\
\hline
\end{tabular}

${ }^{\mathrm{a} O n e-w a y ~ A N O V A ~(b e t w e e n ~ g r o u p s ~ c o m p a r i s o n ~ o f ~ m e a n s) . ~}$

${ }^{b}$ Post-hoc comparisons allow further exploration of the differences between individual groups using the Tukey HSD test, which assumes equal variances for the groups.

${ }^{+}$Significant at .10.

* Significant at 05 .

** Significant at .01 .

Significant at .001

three questions on racial bias perceptions, the mean scores are all below a 2.44 , which means that students as a whole disagree with the idea that the police, courts, and the War on Drugs were fair and treated all racial groups equally. For all three questions, the control group has the highest score, which means that they were closer to agree than the test population. Affirming our first hypothesis, Table 1 indicates that for the students who read The New Jim Crow, their level of knowledge on the topic was greater and they more strongly believed that law enforcement does not treat all racial groups equally.

A one-way analysis of variance (ANOVA) was used to examine whether there were statistically significant differences between the control group and the pretest and posttest scores of the experimental group on four measures. Three of the four measures were found to have statistically significant differences in the means. Table 2 provides the results of the ANOVA tests with post-hoc comparisons (Tukey HSD).

As seen in Table 2, NJC Knowledge, which tests content questions regarding the text, there were significant differences between the control group and the experimental group's pretest and posttest $(F=63.41, p<.001)$. Additionally, a post-hoc comparison of means indicates that there is a statistically significant difference between the control group and pretest, control group and posttest, and lastly, pretest and posttest. No statistical difference was found in our next measure of police's equal treatment of all racial groups. Average responses for this question indicate disagreement (2), with the posttest group being the lowest at 1.76, thus moving closer to strongly disagree (1). There were significant differences found with attitudes about courts treating all people equally $(F=6.63, p>.05)$. The control group was the highest score and the posttest group was the lowest, approaching strongly disagree. The post-hoc comparison found only statistical significance between the control group and the posttest 
Table 3. Gender mean differences.

\begin{tabular}{|c|c|c|c|c|}
\hline \multirow[b]{2}{*}{ Variables } & \multicolumn{4}{|c|}{ Males } \\
\hline & $\begin{array}{l}\text { Control } \mathrm{M} \text { and (SD) } \\
\qquad(n=28)\end{array}$ & $\begin{array}{l}\text { Experimental } \\
\text { pretest } M \text { and (SD) } \\
\qquad(n=30)\end{array}$ & $\begin{array}{c}\text { Experimental } \\
\text { posttest } \mathrm{M} \text { and (SD) } \\
\qquad(n=30)\end{array}$ & Significance $F$ \\
\hline $\begin{array}{l}\text { Police treating } \\
\text { all racial groups } \\
\text { equally }\end{array}$ & $2.11(88)$ & $2.03(.85)$ & $2.07(.74)$ & 0.066 \\
\hline $\begin{array}{l}\text { Courts treating all } \\
\text { racial groups } \\
\text { equally }\end{array}$ & $2.43(.84)$ & $2.18(.85)$ & $2.17(.65)$ & 1.023 \\
\hline \multirow[t]{2}{*}{$\begin{array}{l}\text { The War on Drugs } \\
\text { primarily targets } \\
\text { people of color }\end{array}$} & $2.5(.51)$ & $2.67(.77)$ & $2.33(.66)$ & $2.0379^{+}$ \\
\hline & \multicolumn{4}{|c|}{ Females } \\
\hline Variables & Control $\mathrm{M}$ and (SD) & $\begin{array}{c}\text { Experimental } \\
\text { pretest } \mathrm{M} \text { and }(\mathrm{SD})\end{array}$ & $\begin{array}{c}\text { Experimental } \\
\text { posttest } \mathrm{M} \text { and (SD) }\end{array}$ & Significance $F$ \\
\hline $\begin{array}{l}\text { Police treating } \\
\text { all racial groups } \\
\text { equally }\end{array}$ & $\begin{array}{l}(n=37) \\
2.0(.78)\end{array}$ & $\begin{array}{c}(n=33) \\
1.82(.67)\end{array}$ & $\begin{array}{c}(n=33) \\
1.48(.57)\end{array}$ & $5.062^{* *}$ \\
\hline $\begin{array}{l}\text { Courts treating } \\
\text { all racial groups } \\
\text { equally }\end{array}$ & $2.19(.70)$ & $1.91(.71)$ & $1.48(.57)$ & $9.864 * * *$ \\
\hline $\begin{array}{l}\text { The War on Drugs } \\
\text { primarily targets } \\
\text { people of color }\end{array}$ & $2.4(.80)$ & $2.03(.83)$ & $1.42(.56)$ & $15.31 * * *$ \\
\hline
\end{tabular}

${ }^{a}$ Item was reverse coded.

${ }^{+}$Significant at .10 .

* Significant at .05 .

***ignificant at .01 .

Significant at .001 .

group. The last question regarding student perceptions of the War on Drugs targeting people of color we found strong statistical difference between the control group and the experimental groups' pre and posttests $(F=10.66, p<.001)$. Post-hoc comparisons reveal that there are statistically significant differences between the control group and the posttest, and between the pretests and posttest. Taken together, these results support the second part of our first hypothesis, which stated that exposure to The New Jim Crow makes students less likely to believe that the police and courts treat people of all races equally.

While the descriptive data (Table 1) and ANOVA analyses (Table 2) provided support for the Marshall Hypothesis, we wanted to explore how a person's gender might impact perceptions of racial bias by police, the courts, and the War on Drugs. Table 3 compares the means of responses on these items by gender.

The first portion of Table 3 shows males' mean responses across the control group, and the pretest and posttest measures for the experimental group, where there were no statistical differences. All of the scores were in the range of two, showing a general disagreement that police, courts, and the War on Drugs impacted all racial groups equally. Generally, males in the experimental group had lower scores than the control group and in the posttest, showing a trend toward being persuaded by Alexander's argument in The New Jim Crow. ANOVA analysis of the last measure, War on Drugs 
primarily targets people of color, was approaching significance at the .10 level, if a more liberal cut off was permitted. While there were no significant differences found with the male sample, within the female sample, all three items were found to have significant differences between the control group and the experimental pretest and posttest scores. Similar to the males, all the scores were in the range of two, showing general disagreement that police, courts, and the War on Drugs treated all racial groups equally; however, female scores were closer to "strongly disagree." Statistically significant differences were seen in the first item measuring perceptions of equitable police treatment $(F=5.062, p>.01)$; the second item measuring equitable court treatment $(F=9.86, p>.001)$; and the third item assessing perceptions of the fairness of the War on Drugs with regard to race $(F=15.31, p>.001)$. Support was found for our second hypothesis, that males would show less change in perceptions about the racial bias of police, courts, and the War on Drugs.

\section{Qualitative analysis}

To better understand the impact of Alexander's text on students, a reflective essay was assigned that asked students to critique Alexander's arguments about profiling, arrest rates, and incarceration times that were central artifacts of the War on Drugs. ${ }^{1}$ We employed a kind of grounded theory analysis (Strauss \& Corbin, 1997) that required us to closely read and reread students' essays. After assessing all the papers and determining that all the students read and understood the basic premise of Alexander's book, we explored two central questions pertinent to the project. The first question was, are students persuaded by Alexander's argument? Second, how best can student's responses be coded and categorized to determine a thematic response to Alexander's work? To increase reliability, we coded students' essays independently, and then collectively agreed on the emergence of thematic categories. After analyzing all the papers $(N=63)$, we found three dominant themes: students who were moved toward the author's argument in the text (33\%), students who responded lukewarm to the text $(37 \%)$, and students who resisted the text (30\%). Papers that illustrated movement toward the text contained many of the facts presented by Alexander and also tended to express indignation that the US criminal justice system was having a detrimental impact on people of color. Papers that were deemed to be lukewarm presented fewer facts and exhibited a placid tone. Lastly, papers that showed resistance to the text had clear statements of disagreement with Alexander's points and often included counter-arguments and alternate explanations. While some papers had a mix of being moved and resisting some of the ideas in Alexander's text, we categorized these papers based on their overall tone.

After examining these three categories, we found both males and females were represented in all the groups. We also, however, found that there were noticeable gender differences in the moved and resisted categories. We found $38 \%$ of females in the moved category, as compared with $23 \%$ of males. Additionally, in examining the resisted category, $25 \%$ of female student papers were coded as resisting as compared

${ }^{1}$ Unfortunately, due to the need to protect student confidentiality, we were not able to link the quantitative data to the reflective essay. 
to $37 \%$ of the male student papers. Similar to the survey results presented earlier, we found that more females wrote essays that qualified as being moved, which we identify as demonstrating energetic socio-emotional transformation. In the resisted category, we identified a range of disagreements, which illustrated spirited socioemotional resistance. In this category, there were more males, and the degree of socio-emotional resistance was more prevalent in their papers.

For the sake of time and space, we do not explore or explain in depth the gender similarities of the students in the group thematically coded as lukewarm/mild to no transformation, which comprised a relatively large amount of the students. By lukewarm, we characterize the students' responses as expressing lack and/or absence of comments about Alexander's text being: "eye-opening," "novel," "creating new insight and awareness," or not having made "significant changes" in their beliefs, self-reported actions, attitudes, understandings, and/or behaviors.

Below are two responses (one female and one male) that fit into the thematic category lukewarm/mild to no transformation.

While I agree with her views of racism being present within the legal system of
apprehending, sentencing, and paroling criminals, I do not agree with her views of the
executive branch (specifically Regan) purposefully enacting harsh laws with the intent of
blacks being the primary target. Alexander claims all this started with the intent to
discriminate against African Americans... While at times I do believe the government is
involved in more than it claims to be, I feel like the attempt to minimize drug use was
targeting a specific race is farfetched.

(Megan, white American female)

I wish Alexander had presented both sides of the argument in her critical analysis ... any critical analysis of a subject deserves both sides of the argument presented. What is presented is interesting, but I feel that it deserves further exploration ... there are many sections of Alexander's argument that I do not agree with. I agree with Alexander when she states that in the drug war, police have discretion regarding whom to target as well as where to target. I would have to respectfully disagree, although there were certain aspects of this argument that I found myself agreeing with. The war on drugs has to start somewhere... the most effective way for this to happen is to remove as many members of this delinquent group as possible, which is accomplished through profiling.

(Michael, white American male)

Both respondents above describe and discuss several aspects of Alexander's text that they agree and disagree with; both respondents also concluded their essays without taking a firm stance on whether or not they found the text mentally stimulating, thought-provoking, politically engaging, and/or enlightening. Like many of their peers, they also ignored the significance of race in the historical and contemporary operation of drug policy and the broader US criminal justice system. Our lack of further in-depth description and discussion of the lukewarm/mild group is intentional, chiefly because it enables us to delve deeper into the other two thematic emergent categories, which showed greater differences between males and females. The above notwithstanding, a true null hypothesis would suggest that Alexander's book did not have an impact on the students. However, we did find that a sizable portion of the lukewarm students 
exhibited support for Alexander's work, albeit at a lower level of enthusiasm than the "moved" category. Thus, it can be argued that her work did influence these students.

\section{Energetic socio-emotional transformation}

Students who expressed energetic socio-emotional transformation after reading Alexander's text exhibited two typological responses: surprise and transformative change. Below are three responses from female students, juxtaposed with the responses of two males, all of which fit into the category of energetic socio-emotional transformation. The female respondents began and ended their critical reviews by writing about the ways in which Alexander's text stimulated them by transforming their thinking, understanding, and calls to civic action.

\{Reading\} this book has been an enlightening experience... While I must admit that it was very difficult for me to delve into it, once I had, I was taken on an eye-opening journey through U.S. history in a way that I know I certainly did not learn about during my formative years in school... When I first started out reading this book, I thought that she was being dramatic, exaggerating, and illogically indulging conspiracy theories. After finishing the book, I have come to see her point of view, even appreciate her use of dramatic examples and a serious tone (and why she used them). While I may not fully agree with everything that she said, I can certainly appreciate her passion for educating others through her book, her passion for justice. I also embarrassed myself by not knowing much of the history involving racism in our country, and the ways in which it has seemingly morphed with society to contain politically correct language, to be socially and culturally acceptable.

(Ashly, white American female)

(Alexander's book\} certainly opened my eyes and brain to a whole new concept about the way American society works specifically drawing on the high incarceration rates in this country. One thing I appreciate is how well organized, researched and written the book is .... No other country incarcerates a larger percentage of its black population than the U.S ... I think Alexander did a great job of raising these issues and incorporating valid and relevant statistics along the way to probe her point. It definitely opened my mind to the other side of the issue.

(Sarah, white American female)

I agree with Michelle Alexander that our society has reentered an era of social caste. I never knew that these problems were present in our nation. My entire upbringing, I have always been taught to accept all individuals and treat everyone equal, no matter the color of their skin or ethnic backgrounds. I never looked at those of color as criminals unless they truly were. My eyes have now been opened to a new issue of discrimination and mass incarceration...

(Jessica, white American female)

The three female responses above all discuss the significance of race within the contemporary operation of the US criminal justice system. Ashly, Sarah, and Jessica all describe the eye-opening impact of Alexander's text, comprised of her grand argument, evidence, and conclusions. In many ways, the respondents above tell much 
about Alexander's influence on their thinking about crime and punishment in the United States, and express appreciation for being informed about the impact of systemic racism in the US criminal justice system. Below are a few males' responses, which mirror the initial reactions and responses of the female students.

I agree with her arguments... Before studying this book, I did not know the war on drugs was anywhere near as unfair as it is ... Anybody with a conscience should realize that what is happening to the minorities due to the war on drugs is downright wrong. Crime and punishment in America are very poorly correlated on society... People who read her book should try to create reform in the justice system and share the knowledge they read about in this book with the rest of society. The more people know about this crisis will increase the probability reform will take place sometime in their future, hopefully.

(Eli, white American male)

\{Alexander's book is\} a great eye opener into a world that most people do not know about... a racial difference still segregates us in the legal system today. Before reading this book I never contemplated an idea like this, but it does make a good amount of sense. I think I always thought that there was just a greater amount of African Americans that commit crimes. On the contrary, I think the percentages if you look at some other social classes between whites and blacks, committing crimes are roughly the same. It just turns out that many more minorities get charges for those crimes and reside in a lower socio-economic class than whites.

(Christopher, white American male)

Like the females' responses, the males' responses demonstrate the surprising and eye-opening impact of Alexander's text. The males, however, amplify their supportive stance of Alexander's findings through their assertions that what is happening to minorities is "wrong" and "contrary" to the ways they previously thought about the relationships between race, crime, and punishment in US criminal justice system. Eli poses social-ethical change via personal calls for action and needs to rectify the "crisis" of the disproportionate punishment of minorities. Christopher asserts race and racism "still segregates" offenders in ways reflective of the disproportionate charges and sentences of lower class racial and ethnic minorities.

\section{Spirited socio-emotional resistance}

Despite the aim of Alexander's text, there were students who resisted the facts presented. Overall, more males than females comprised this emergent thematic group; males' responses tended to be harsher, highly charged, and supportive of US drug policy and the criminal justice system, all the while being contradictory in nature and their explanations. Below are four responses (one female and three males) that we thematically characterized as exemplary of spirited socio-emotional resistance. Two of the students began and ended their critical reviews using the same argument and position (one female and one male). The other two male students (typical of many other males in our study); however, contradicted themselves in their opening explanations of the impact of Alexander's text. Below are the first set of categorical responses juxtaposed with the other set of categorical responses. 
After reading the book, I would say that all together, I would disagree with a majority of what she has to say... she is implying and stating that minorities, mainly African Americans, are purposely targeted and aimed at putting behind bars when it comes to drugs. This is something I completely disagree with. African Americans may have a higher number of inmates within the prisons, for multiple reasons, but this is not because the justice system specifically targets them. They are valued and seen just as any other American, no matter what race. I would agree that they do create a stereotype for themselves and that generally takes a toll on other's opinions of how the justice system operates.... African Americans are valued now more equally as any other race than they ever have been. They are human beings, and have free will. They are able to make their own decisions and what they do in life, and have to deal with the consequences just like anyone else would have to. This cannot be blamed on the police officers or the justice system because this is something that can be avoided by choice. I feel as if young African Americans are not "targeted" necessarily, but rather are watched more closely when it comes to crime and violence in specific areas ... Do I think there some racial stereotyping behind this? Of course. However, I do believe that in a way African Americans create this type of behavior with the way they act, and a lot of that has to do with where they live, who they associate themselves with, and how they present themselves... It is just frustrating to read that African Americans still feel as if they are getting targeted, when really it is just a matter of whether you broke the law or not... It is always important to remember that you have a choice. You have a choice to choose right from wrong, and if you choose to do wrong then you will consequently deal with what is justice.

(Emily, white American female)

After reading this book I appreciate what Alexander is trying to do, but I do not agree with the general beliefs she has... if the inner city is where the majority of crack cocaine is being used and dealt, then the inner city should be targeted by police. Otherwise, the police would be wasting their time looking in other areas. If the purpose of the war on drugs was to get a crack cocaine off of the streets, then the police did the right thing. Unfortunately, the majority of the inner city's population is composed of minorities.... She attempts to explain that it is wrong to target people of Latino descent as illegal immigrants. However, after looking at the facts, the majority of illegal immigrants are Mexican. I believe that the Supreme Court did this to allow the police to do their jobs, and not be sued every step of the way just because the person they arrested was a person of color... The there's no doubt that a felon has fewer rights and benefits than a normal member of society, but shouldn't that be the case? Shouldn't those who behave be rewarded, and those who break society's rules suffer the consequences? Drug offenders in United States will spend considerably more time in prison, probation and parole than any other nation. This does make sense to me because if our goal is to eliminate or reduce drug abuse, then harsher sentencing should do the job... If our goal is to put away hundreds of thousands of criminals, then we're on track.

(Ethan, white American male)

The female and male responses above demonstrate spirited socio-emotional resistance from the beginning of their critical review assignment, through the end. Both respondents address counter arguments based on notions about Alexander's implications and beliefs, citing free will, life choices and chances. Furthermore, both respondents engage in the discussions about freedom, justice, and equality for all, while failing to address clear racial imbalances in profiling, arrest rates, incarceration times and rates. 
The final two respondents in our thematic category - spirited socio-emotional resistance - contradict many of their aforementioned statements that are originally reflective of energetic socio-emotional transformation. Like many other males in this study, the two respondents below refute Alexander's arguments.

There are parts of Alexander's message I disagree with. The bottom line is that if people do not break the law, no matter what race are, they will not go to prison.... Her whole book is for people of color that have broken the law doing related crimes. If they are an adult and have broken the law for drug related crimes, or any crime, they should go to prison. It is hard to say that law enforcement agencies are targeting African Americans... Police are going to go where the crime is. If African Americans are the ones committing crimes, the police are going to go to those areas to stop the crime. There is something to be said for how many African Americans are in prison. I do believe there needs to be some work on the criminal justice system, but I do not think it is to the extent that Alexander makes it out to be.

(James, white American male)

I also thought that Alexander took her book a little bit to the extreme... She makes it seem like every cop is crooked and that our judicial system is out to imprison minorities. I think that our government started the war on drugs to truly take back the streets... I think there was an undetermined consequence of those actions that eventually led to the mass incarceration of African Americans ... I think a good way to look at any situation in the field is to be open minded and treat every suspect in a similar matter if they are black, white, yellow, or blue... After reading all the facts given in the book, it is impossible to overlook the racial narrow mindedness that is taking place... I think racial stereotyping is going way down. My classmates and I see a different racial student as just another individual that is as equal to everybody else. Our parents and grandparents have more racial stereotypes than the ones we do because they grew up in Jim Crow. My classmates and I have grown up in a world that has been more equal than ever, we elected an African American president!

(Luke, white American male)

The two male respondents above avoid any significant engagement with understanding racial bias and discrimination in the US criminal justice system. Instead, both students reaffirm the notion that the War on Drugs was racially impartial, and is just a hyper figment of the racial imagination of African Americans and other people of color. These two respondents also affirm the belief in choices and the notion of a race neutral just punishment for crime which fails to understand racial profiling as an antiquated police practice.

\section{Discussion and conclusion}

Our study found support for the Marshall Hypothesis with regards to examining undergraduate students' perceptions of US drug policy. While our sample as a whole reported that many students believed law enforcement did not treat all racial groups equally prior to reading the book, we found in the posttest scores that exposure to the content of The New Jim Crow did have a statistically significant impact on moving students toward a stronger opinion regarding the lack of equality. Similar to studies conducted on the impact of exposure to knowledge about the death penalty, having 
a greater understanding of the issue shifts students' positions from support to nonsupport (Bohm, Clark \& Aveni, 1991; Cochran \& Chamlin, 2005; LaChappelle, 2012; Lambert, Camp, Clarke \& Jiang, 2011; Lambert \& Clarke, 2001; Mallicoat \& Brown, 2008; Michel \& Cochran, 2011; Mitchell, 2006). Echoing these findings, our current study demonstrates that exposure to The New Jim Crow does have an impact on students' perceptions of racial bias and discrimination in US drug policy. As instructors that wish to assign thought-provoking research to create more informed citizens who are socially conscious, this finding, on the surface, demonstrates what Thurgood Marshall had believed: that justice will (hopefully) prevail if subjects are informed.

While we found support for the idea of knowledge impacting perceptions toward justice, this study's inclusion of racism as a central factor in creating unequal outcomes in US drug policy is more difficult to combat with knowledge alone. The sheer entrenchment of racist ideology permeates the US consciousness in a way that is difficult to dismantle. The statistical evidence of movement toward strongly disagreeing that US law enforcement and the penal system treat all people fairly, regardless of race, was largely yielding impact on the females in our sample. Qualitative analysis of student's critical reviews indicates that there is greater resistance among male students who made up larger percentages within the categories of mild to no transformation or spirited socio-emotional resistance, after initially appearing to praise Alexander's text.

Our efforts to produce more properly informed constituents with scholarly research that can bring about a more just and equitable US drug policy is not a failed attempt, in and of itself. Instead, our findings demonstrate that presenting some students with a best-selling, academically acclaimed text is not sufficient to countering deep-seated racial biases and discrimination that permeate white (largely male) college students' minds. Changing perceptions of racial bias and discrimination, for some, requires more intentionally directed efforts, such as semester-long courses specifically on the topic of racial bias and discrimination in policing, or having direct experiences with communities of color disproportionately impacted by US drug policies. A service learning course where students volunteer at juvenile detention centers or other correctional facilities have been found to impact citizens' perceptions as well (Conway, Amel, \& Gerwien, 2009).

While Alexander's text may be convincing for some students and lead to changed attitudes, the focus on racial discrimination as a direct cause of policy is perhaps triggering what various scholars have identified as implicit bias, which is the attitudes or stereotypes which affect our unconscious beliefs (Cameron, Payne, \& Knobe, 2010; Devine, 1989). Challenging deep seated racial bias requires that individuals become aware of their biases and then, because of concern about the consequences of this bias, they are moved to change. Exposure to The New Jim Crow, on its own, is not sufficient enough to challenge some of these implicit biases.

It is important that we interrogate the significance of our research results in concert with the comments from the late John Ehrlichman, President Richard Nixon's Assistant for Domestic Affairs, concerning President Nixon's declaration of "A War on Drugs." Ehrlichman said,

You want to know what this was really all about? The Nixon campaign in 1968, and the Nixon White House after that, had two enemies: the antiwar left and black people. You understand what I'm saying? We knew we couldn't make it illegal to be either against the 
war or black, but by getting the public to associate the hippies with marijuana and blacks with heroin, and then criminalizing both heavily, we could disrupt those communities. We could arrest their leaders, raid their homes, break up their meetings, and vilify them night after night on the evening news. Did we know we were lying about the drugs? Of course we did. (Baum, 2016)

Ehrlichman's statement, which correlates with the evidence that Alexander presents in The New Jim Crow, reveal much more about the category of spirited socio-emotional resistance found in some college students' critical reviews that deny African Americans' racial realities within the US criminal justice system. Ehrlichman's comments, like our study of the impact of Alexander's text, demonstrate how many white Americans are unable to imagine or comprehend systems of socio-political control designed to privilege some and hinder others. Nonetheless, the powerful truth that Alexander presents has planted a seed in the minds of these readers to (hopefully) germinate and eventually blossom into fruitful action.

\section{Limitations}

While this study advances research in the area of applying the Marshall Hypothesis in new avenues, there are several limitations that should be noted in considering our results. Both our quantitative and qualitative approaches were not completely free of social desirability bias. The tendency of students to answer our questions in a manner highly favorable in order to receive a desired grade is something we considered. It was interesting though that in a Likert scaled question when students were asked to strongly agree, agree, disagree or strongly disagree that the police or the courts treated all people equally, regardless of race, most students indicated that they disagreed with those statements. Yet, when students were asked to reflect on Alexander's main points, which specifically discuss how both the police and the court system are creating a new "Jim Crow" style of segregation within our society, some students showed a great deal of resistance to these ideas or were simply not moved by the evidence. Thus, it appears that the pressure to be socially acceptable is greater in a survey context, but when students are asked to reflect on the issue in five pages, their true feelings present themselves. We were unable to compare individual students' survey responses to their reflective essays because the survey was anonymous.

Generalization of findings to a broader student population is also limited because of the single-institution sample. Future research could replicate this study in different kinds of higher educational institutions and include larger samples. Additionally, including a specific scale within the survey that is designed to measure racial attitudes, such as the Modern Racism Scale (McConahay, 1986), may aid in understanding the spirited socio-emotional resistance we observed. Additionally, future studies should also consider how conventional pedagogy, such as lectures and readings, compare to exposure to experiential learning in changing attitudes regarding US drug policy. Exposure to knowledge alone may not be enough to reach all individuals without engaging them in a personal emotional experience. Such interventions as perspective taking of the stigmatized other or imagining counter-stereotypic examples have been found to reduce implicit bias (Dasgupta \& Greenwald, 2001; Galinsky \& Moskowitz, 2000) Additionally, active pedagogies, such as service learning or problem based 
learning, may illicit the emotional response that moves students to transformational change.

\section{Disclosure statement}

The authors declared no potential conflicts of interest with respect to the research, authorship and/or publication of this article.

\section{Notes on contributors}

Richard D. Clark is an Associate Professor who teaches courses in criminological theory, drugs and crime, and violence.

Gloria Vaquera is an Associate Professor whose research interests focus on diversity in higher education and teaches courses in race and ethnicity, Latinx studies and research methods.

Kenneth Sean Chaplin, is an Assistant Professor who teaches courses in the area of race and ethnicity, culture and the sociology of sport.

\section{References}

Abramsky, S. (2009). The War Against the 'War on Drugs' - Economic necessity and shifting mores are changing the nation's approach to incarceration. Nation, 289(1), 18-22.

Alexander, M. (2010). The new Jim Crow: Mass incarceration in the age of colorblindness. The New Press.

Baum, D. (2016). Legalize it all. Harper's Magazine, 24. https://harpers.org/archive/2016/04/legalizeit-all/

Bohm, R. M., Clark, L. J., \& Aveni, A. F. (1991). Knowledge and death penalty opinion: A test of the Marshall hypotheses. Journal of Research in Crime and Delinquency, 28(3), 360-387. doi: $10.1177 / 0022427891028003006$

Blumer, H. (1958). Race prejudice as a sense of group position. Pacific Sociological Review, 1(1), 3-7. doi:10.2307/1388607

Cameron, C. D., Payne, B. K., \& Knobe, J. (2010). Do theories of implicit race bias change moral judgments? Social Justice Research, 23(4), 272-289. doi:10.1007/s11211-010-0118-z

Carter, R. T. (1990). The relationship between racism and racial identity among White Americans: An exploratory investigation. Journal of Counseling \& Development, 69(1), 46-50. doi:10.1002/ j.1556-6676.1990.tb01455.x

Cochran, J. K., \& Chamlin, M. B. (2005). Can information change public opinion? Another test of the Marshall hypotheses. Journal of Criminal Justice, 33(6), 573-584. doi:10.1016/j.jcrimjus.2005.08.006

Cochran, J. K., \& Sanders, B. A. (2009). The gender gap in death penalty support: An exploratory study. Journal of Criminal Justice, 37(6), 525-533. doi:10.1016/j.jcrimjus.2009.09.001

Conway, J. M., Amel, E. L., \& Gerwien, D. P. (2009). Teaching and learning in the social context: A meta-analysis of service learning's effects on academic, personal, social, and citizenship outcomes. Teaching of Psychology, 36(4), 233-245. doi:10.1080/00986280903172969

Dasgupta, N., \& Greenwald, A. G. (2001). On the malleability of automatic attitudes: combating automatic prejudice with images of admired and disliked individuals. Journal of Personality and Social Psychology, 81(5), 800 doi:10.1037//0022-3514.81.5.800

Devine, P. G. (1989). Stereotypes and prejudice: Their automatic and controlled components. Journal of Personality and Social Psychology, 56, 5-18. doi:10.1037/0022-3514.56.1.5

Feloni, R. (2015). Why Mark Zuckerberg wants everyone to read 'The New Jim Crow. Business Insider. http://www.businessinsider.com/mark-zuckerberg-the-new-jim-crow-2015-5 
Galinsky, A. D., \& Moskowitz, G. B. (2000). Perspective-taking: decreasing stereotype expression, stereotype accessibility, and in-group favoritism. Journal of Personality and Social Psychology, 78(4), 708. doi:10.1037//0022-3514.78.4.708

Gallup Polling. (2013). US death penalty support stable at 63\%. January 9, 2013

LaChappelle, N. L. (2012). Placing the American death penalty in the global context: A test of the Marshall hypothesis. Santa Barbara: University of California.

Lambert, E. G., Baker, D. N., Elechi, O. O., Jiang, S., Khondaker, M. I., Pasupuleti, S., \& Hogan, N. L. (2016). Gender and cultural differences on death penalty support and views among Indian and US college students. Journal of Ethnicity in Criminal Justice, 1-18. doi:10.1080/ 15377938.2015.1015195

Lambert, E. G., Camp, S. D., Clarke, A., \& Jiang, S. (2011). The impact of information on death penalty support, revisited. Crime \& Delinquency, 57(4), 572-599. doi:10.1177/0011128707312147

Lambert, E., \& Clarke, A. (2001). The impact of information on an individual's support of the death penalty: A partial test of the Marshall hypothesis among college students. Criminal Justice Policy Review, 12(3), 215-234. doi:10.1177/0887403401012003003

Lambert, E. G., Clarke, A., \& Lambert, J. (2004). Reasons for supporting and opposing capital punishment in the USA: A preliminary study.

Lee, J., \& Gibbs, J. C. (2015). Race and attitudes toward police: The mediating effect of social distance. Policing: An International Journal of Police Strategies \& Management, 38(2), 314-332. doi:10.1108/PIJPSM-03-2015-0034

Lewis, L. M., Wilks, S. E., Geiger, J. R., Barthelemy, J. J., \& Livermore, M. M. (2017). A racial divide: College student attitudes concerning police in South Louisiana. Journal of Pan African Studies, 10(1).

Mallicoat, S. L., \& Brown, G. C. (2008). The impact of race and ethnicity on student opinions of capital punishment. Journal of Ethnicity in Criminal Justice, 6(4), 255-280. doi:10.1080/ 15377930802530296

Mbuba, J. M. (2010). Attitudes toward the police: The significance of race and other factors among college students. Journal of Ethnicity in Criminal Justice, 8(3), 201-215. doi:10.1080/ 15377938.2010.502846

McConahay, J. B. (1986). Modern racism, ambivalence, and the Modern Racism Scale. In J. F. Dovidio \& S. L. Gaertner (Eds.), Prejudice, discrimination, and racism (pp. 91-125). San Diego, CA, US: Academic Press.

Michel, C., \& Cochran, J. K. (2011). The effects of information on change in death penalty support: race-and gender-specific extensions of the Marshall hypotheses. Journal of Ethnicity in Criminal Justice, 9(4), 291-313. doi:10.1080/15377938.2011.609430

Mitchell, A. D. (2006). The effect of the Marshall hypothesis on attitudes toward the death penalty. Race, Gender \& Class, 221-247.

Morin, R., \& Stepler, R. (2016). The racial confidence gap in police performance. Pew Research Center. $\quad$ http://www.pewsocialtrends.org/2016/09/29/the-racial-confidence-gap-in-policeperformance/

Oliveira, A., \& Murphy, K. (2015). Race, social identity, and perceptions of police bias. Race and Justice, 5(3), 259-277. doi:10.1177/2153368714562801

Pew Research Center. (2015). Less support for death penalty, especially among democrats.

Qualls, R. C., Cox, M. B., \& Schehr, T. L. (1992). Racial attitudes on campus: Are there gender differences? Journal of College Student Development, 33, 524-530

Resnick, B. (2015). Eric Holder keeps chipping away at the 'War on Drugs.' The Atlantic. https:// www.theatlantic.com/politics/archive/2015/01/eric-holder-keeps-chipping-away-at-war-ondrugs/453483/

Sarat, A., \& Vidmar, N. (1976). Public opinion, the death penalty, and the eighth Amendment: Testing the Marshall hypothesis. Wisconsin Law Review, 171-206.

Strauss, A., \& Corbin, J. M. (1997). Grounded theory in practice. Sage.

Stack, S. (2000). Support for the death penalty: A gender-specific model. Sex Roles, 43, 171-206 
Terenzini, P. T., Pascarella, E. T., Springer, L., Nora, A., \& Palmer, B. (1996). Attitudes toward campus diversity: Participation in a racial or cultural awareness workshop. The Review of Higher Education, 20(1), 53-68. doi:10.1353/rhe.1996.0003

Weitzer, R. (2015). American policing under fire: Misconduct and reform. Society, 52(5), 475-480. doi:10.1007/s12115-015-9931-1

Weitzer, R., \& Tuch, S. A. (1999). Race, class, and perceptions of discrimination by the police. Crime \& Delinquency, 45(4), 494-507. doi:10.1177/0011128799045004006

Zedillo E. \& Wheeler, H. (2012). Rethinking the war on drugs through the US-Mexico prism. New Haven, CT: Betts House 